\title{
Anthelmintic Activity of Fruit Extract and Fractions of Piper longum L. In vitro
}

\author{
Krishnaprasad Ganapati Koorse ${ }^{1 *}$, Sujith Samraj', Preethy John1', Priya Manakkulaparambil Narayanan², Devi \\ Suma Thankachy Sreekantan Thampy ${ }^{3}$, Usha Parackal Thachappully Ayyappan', Surya Sunilkumar', Gleeja Villan \\ Lonappan ${ }^{4}$
}

\section{Krishnaprasad Ganapati Koorse ${ }^{1 *}$, Sujith Samraj', Preethy John ${ }^{1}$, Priya Manakkulaparam- bil Narayanan², Devi Suma Thankachy Sreekantan Thampy ${ }^{3}$, Usha Parackal Thachappully Ayyappan', Surya Sunilkumar' ${ }^{1}$, Gleeja Villan Lonappan ${ }^{4}$}

'Department of Veterinary Pharmacology and Toxicology, College of Veterinary and Animal Sciences, Mannuthy, Thrissur, Kerala, INDIA. ${ }^{2}$ Department of Veterinary Parasitology, College of Veterinary and Animal Sciences, Mannuthy, Thrissur, Kerala, INDIA.

${ }^{3}$ Department of Veterinary Pathology, College of Veterinary and Animal Sciences, Mannuthy, Thrissur, Kerala, INDIA.

${ }^{4}$ Department of Statistics, College of Veterinary and Animal Sciences, Mannuthy, Thrissur, Kerala, INDIA.

\section{Correspondence}

Krishnaprasad GK

MVSc Scholar Department of Veterinary Pharmacology and Toxicology, College of Veterinary and Animal Sciences, Mannuthy, Thrissur, Kerala-680651, INDIA.

Phone No: 09480485209

E mail Id: kpvet.kgvk@gmail.com

History

- Submission Date: 28-9-2017

- Review completed: 15-10-2017.

- Accepted Date: 19-12-2017

DOI : 10.5530/pj.2018.2.57

Article Available online

http://www.phcogj.com/v10/i2

\section{Copyright}

(C) 2018 Phcog.Net. This is an openaccess article distributed under the terms of the Creative Commons Attribution 4.0 International license.

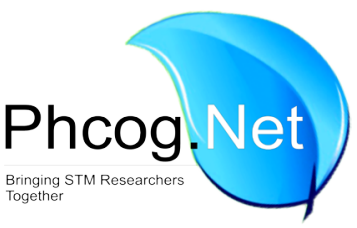

\section{ABSTRACT}

The present study was aimed to assess the in vitro ovicidal, larvicidal and adulticidal activity of methanolic extract and its fractions from fruits of Piper longum against strongyle ova, larvae and adult amphistomes respectively. The fruits of $P$. longum was identified and the accession number 006 was obtained. The phytochemical analysis revealed the presence of tannins, flavonoids, glycosides, phenolics, diterpenes and triterpenes in extract and fractions of $P$. longum. The extract and fractions were diluted serially in 6.25 per cent tween 80 to obtain concentrations of $500,250,125,62.5,31.25,15.63,7.81,3.91$ and $1.95 \mathrm{mg} / \mathrm{mL}$. Ivermectin and thiabendazole at $10 \mu \mathrm{g} / \mathrm{mL}$ acted as positive controls and 6.25 per cent tween 80 as negative control. The methanolic extract was highly active against ova with $I_{50}$ of $0.026 \mathrm{mg} / \mathrm{mL}$. The $\mathrm{n}$-hexane fraction was potent in inducing larval mortality with $\mathrm{IC}_{50}$ of $1.383 \mathrm{mg} / \mathrm{mL}$ while chloroform fraction inhibited larval migration with $\mathrm{IC}_{50}$ of $1.796 \mathrm{mg} / \mathrm{mL}$. Amphistomes were highly sensitive for methanolic extract of $P$. longum which possessed $I C_{50}$ of $5.493 \mathrm{mg} / \mathrm{mL}$ Based on $I C_{50}$ values, the methanolic extract was found to be most potent while chloroform fraction was effective against ova, larvae and also adults. GCMS analysis of potent methanolic extract revealed the presence of piperidinone, hydrocinnamic acid, ethylhexahydro azepine, methyleugenol, hexadecanoic acid and caryophyllene oxide which may have contributed for the anthelmintic activity. The acute oral toxicity study revealed mild vascular changes in liver. From the present study, it can be concluded that chloroform fraction of $P$. longum possessed maximum broad spectrum anthelmintic activity comparable to controls. Key words: Adulticidal, GCMS, $I_{50}$, Larvicidal, Ovicidal, Piper longum.

\section{INTRODUCTION}

Gastrointestinal nematode infections are one of the major causes for stunted economic development in livestock sector ${ }^{1}$ due to loss of productivity among livestock in terms of milk, meat, wool, body weight gain etc. ${ }^{1,2,3}$ Many of these helmintic infections have been reported to be zoonotic and thus have become a public health issue. ${ }^{4}$ Though various methods like vaccination, biological control, resistant host etc. has been described, use of anthelmintic drugs (Benzimidazoles, Avermectins or Imidazothiazoles) have its own unique importance in combating these helminth infections. ${ }^{5,6}$ Unfortunately, extensive and indiscriminate use and sole dependency on these chemical drugs resulted in occurrence of resistance to the drugs., Failure to follow the specified withdrawal period after treatment led to accumulation of anthelmintic agent as residues in food chain. ${ }^{9}$

To control gastrointestinal nematode infections and to combat with rising anthelmintic resistance, it is very much necessary to think of some alternatives. This has highlighted the advantages of herbal remedies as an alternative. The plant derived natural substances have been used since past as anthelmintic agent and have been reported to be cheaper, more reliable and less toxic. ${ }^{10}$ Piper longum (Tippali) belonging to the family piperaceae is widely used as medicinal plant for respiratory disorders, insomnia, epilepsy, hemiplegia, vitamin $\mathrm{B}_{1}$ deficiency, fever, stroke and polypepsia. ${ }^{11}$ In this study, the methanolic extract and its fractions were evaluated for ovicidal and larvicidal activity against strongyle ova and larvae respectively. The adulticidal activity was assessed against adult amphistomes.

\section{MATERIALS AND METHODS}

All the solvents and chemicals were of standard and analytic grade and the experimental solutions were freshly prepared.

\section{Plant and extraction}

The fruits of Piper longum were purchased from local vendors and was identified and authenticated at St. Thomas College, Thrissur, India. The voucher specimen was deposited at their repository and accession number was obtained. The collected fruits 
were shade dried, pulverized and subjected to methanolic extraction using soxhlet apparatus. The methanolic extract was dried using rotary vacuum evaporator (Bouchi) and further fractionated to obtain n-hexane, chloroform, n-butanol and aqueous fractions. ${ }^{12}$ The extract and all fractions were stored under refrigeration $\left(4^{\circ} \mathrm{C}\right)$ until further use.

\section{Strongyle ova and larvae}

The faecal samples were collected from various ruminant farms and were subjected to coprological examination. The ova were isolated by routine concentration method and the $\mathrm{L}_{3}$ strongyle larvae were obtained by coproculture of positive faecal samples. ${ }^{13,14}$

\section{Phytochemical screening of the extracts}

The extract as well as the fractions was analysed qualitatively for various phytochemical constituents. ${ }^{15}$

\section{In-vitro anthelmintic activity study Extract dilutions and stock drug solutions}

The methanolic extract and the fractions were serially diluted in 6.25 per cent tween 80 to obtain concentrations of $500,125,62.5,31.25,15.63$, $7.81,3.91$ and $1.95 \mathrm{mg} / \mathrm{mL}$. Ivermectin and thiabendazole at $10 \mu \mathrm{g} / \mathrm{mL}$ were used as positive control and 6.25 per cent tween 80 served as negative control. ${ }^{16}$

\section{Egg hatch assay (EHA)}

The egg hatch assay was done as per the standard procedures described previously. ${ }^{17}$ Freshly isolated eggs were incubated in six well plates in serial dilutions of the plant extract/fractions of $P$. longum, as well as the standard drugs and solvent for $48 \mathrm{~h}$, after which they were fixed with Lugol's iodine. ${ }^{18}$ The numbers of hatched larvae and unhatched eggs were counted. The per cent inhibition of hatching and the concentration of extracts required to inhibit 50 per cent of the eggs from hatching $\left(\mathrm{IC}_{50}\right)$ were calculated.

\section{Larval motility assay (LMA)}

The larvicidal activity of methanolic extract and its fractions of $P$. longum were done according to previous publication. ${ }^{19}$ The motility of third stage $\left(\mathrm{L}_{3}\right)$ larvae was recorded on exposure to the extract and fractions from fruits of P. longum. The cessation of motility of the larvae was considered as end of experiment. The motility of the larvae was observed by light microscopy at $6^{\text {th }}$ and $12^{\text {th }} \mathrm{h}$ and the number of motile and non-motile larvae were counted. The results were expressed as per cent inhibition of larval motility.

\section{Larval migration inhibition assay (LMIA)}

The larval migration inhibition assay was done as described previously. ${ }^{20}$ For LMIA, $1.8 \mathrm{~mL}$ of the test mixture containing $1690 \mu \mathrm{L}$ water, $90 \mu \mathrm{L}$ serially diluted concentrations of the extract of $P$. longum/ control drugs $(10 \mu \mathrm{g} / \mathrm{mL}) / 6.25$ per cent tween 80 and $20 \mu \mathrm{L}$ larval solution containing 90-100 larvae were added to each well of 24 well incubation plates. The plates were incubated in dark at $28^{\circ} \mathrm{C}$ for $24 \mathrm{~h}$.

A second set of plates (migration plates) were prepared with $400 \mathrm{~mL}$ agar (bacto agar, concentration of 1.5\%) in each well of row 1 and 3 of the 24 well plates. After $24 \mathrm{~h}$, the suspensions from the incubation plates (liquid plus larvae) were carefully transferred onto the top of the sieves, suspended above the agar in rows $\mathrm{A}$ and $\mathrm{C}$ of the migration plate (Figure 1). Larvae were left to migrate for $24 \mathrm{~h}$ at $28^{\circ} \mathrm{C}$. The ability of larvae to migrate was determined and expressed as per cent migration inhibition.

\section{Adulticidal assay on amphistomes}

Adulticidal activity was done as described earlier. ${ }^{21}$ Extracts and fractions were diluted in tyrode's solution in petri plates to get a total volume of $20 \mathrm{~mL}$. Tyrode's solution served as negative control while IVM and TBZ at $10 \mu \mathrm{g} / \mathrm{mL}$ each were used as positive control. Six amphistomes were placed in the extract/fractions containing petriplates and the motility/ wriggling movements of amphistomes were noted every $15 \mathrm{~min}$ and lack of movement even on stimulation indicated mortality of amphistomes. The time and concentration at which 50 per cent mortality was recorded.

\section{Selection of potent extract/fraction}

Quantification of dose required for 50 per cent anthelmintic response or the dose required to cause 50 per cent anthelmintic activity was calculated using computer software graph pad prism ver. 6 and is designated as inhibitory concentration-50 ( $\left.\mathrm{IC}_{50}\right)$. The potent extract/fraction was selected based on this $\mathrm{IC}_{50}$ values, obtained from the in-vitro studies.

\section{FTIR and GCMS analysis of potent extract/fraction Fourier transform infrared spectroscopy (FTIR)}

FTIR spectrum of the potent extract/fraction was obtained by conventional $\mathrm{KBr}$ pellet/disc method using Perkin-Elmer FTIR spectrometer. ${ }^{22}$ Two mg of extract/fraction and $298 \mathrm{mg}$ of $\mathrm{KBr}$ (Potassium Bromide) was mixed and placed into an evacuable die on a hydraulic laboratory press and compressed under eight-ton pressure to form a pellet. The $\mathrm{KBr}$ pellet was placed in the pellet holder and spectrum was taken from $4000 \mathrm{~cm}^{-1}$ to $400 \mathrm{~cm}^{-1}$ wave number range using IR spectrophotometer against the blank (300 mg KBr pellet). The spectrum obtained was compared with FLUKA library provided by Perkin-Elmer.

\section{Gas chromatography-Mass spectrometry (GC-MS)}

The GC-MS analysis of the potent extract/fraction was carried out on Thermo Fisher Scientific TSQ 8000 GCMS, as per protocol described earlier. ${ }^{23}$ The potent extract/fraction was dissolved in methanol, filtered in 0.22-micron syringe filter and the compounds were separated on TSQ-2MS capillary column $(30 \mathrm{~m} \times 0.25 \mathrm{~mm}$; i.e., $0.25 \mu \mathrm{m}$ film). The column oven temperature was programmed from an initial temperature of $40^{\circ} \mathrm{C}(3 \mathrm{~min})$ to $160^{\circ} \mathrm{C}$ at $8^{\circ} \mathrm{C} \mathrm{min}^{-1}$, then to $300^{\circ} \mathrm{C}$ at $15^{\circ} \mathrm{C} \mathrm{min}{ }^{-1}$ with a final time of $10 \mathrm{~min}$. The injection temperature and ion source temperature were 250 and $23^{\circ} \mathrm{C}$, respectively. Helium was used as the carrier gas with a flow rate of one $\mathrm{mL} \mathrm{min}^{-1}$. The ionizing energy was $70 \mathrm{eV}$. All data were obtained by collecting the full-scan mass spectra within the scan range 40-350 amu. Compounds were identified using the National Institute of Standards and Technology (NIST) MS Search 2.0 library.

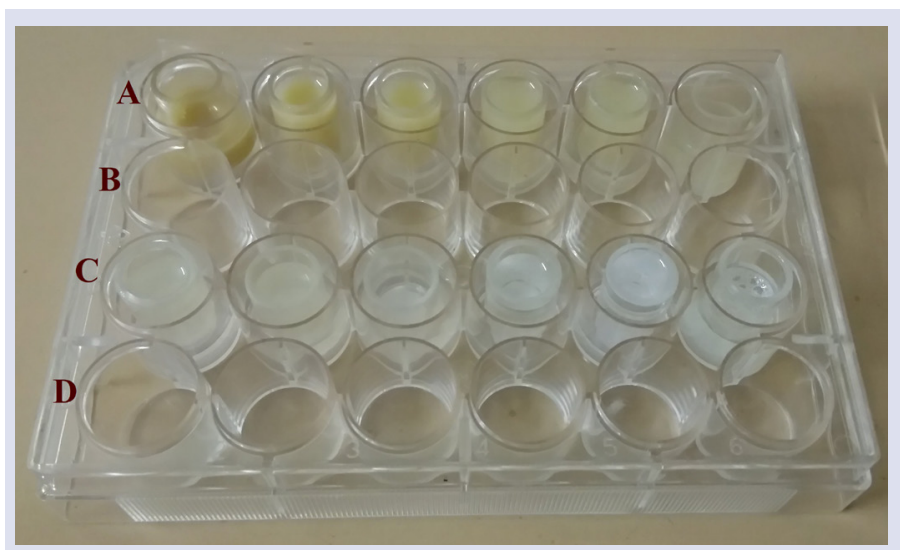

Figure 1: LMIA set up in a 24 well migration plate. 


\section{Acute toxicity study of potent extract/fraction}

Acute oral toxicity study of the potent extract/fraction from fruits of $P$. longum was performed as per the Organization for Economic Co-operation and Development (OECD) guidelines for testing of chemicals, Test No. 420, acute oral toxicity-fixed dose $(2000 \mathrm{mg} / \mathrm{kg})^{24}$

\section{Statistical analysis}

The statistical analysis was performed for the data obtained. The $\mathrm{IC}_{50}$ values were computed using computer software Graph Pad Prism version 6.0. One-way ANOVA was employed to statistically analyse the data of in vitro studies of EHA, LMT and LMIA at $\mathrm{P}<0.05$ using computer software SPSS version 21 .

\section{RESULTS}

\section{Phytochemical screening of the extracts}

The methanolic extract and its fractions from fruits of $P$. longum were subjected to qualitative analysis of phytochemical constituents, the results of which are given in Table 1.

\section{In-vitro anthelmintic activity study}

\section{Egg hatch assay (EHA)}

The results of EHA for the extracts and fractions from fruits of $P$. longum are presented in Table 2. The efficacy of methanolic crude extract of P. longum in inhibiting hatching of strongyle eggs was found to be highest compared to all its fractions. Complete inhibition of egg hatching was observed at 500, 250 and $125 \mathrm{mg} / \mathrm{mL}$ which were more than inhibition produced by ivermectin and thiabendazole ( 98.97 and 99.26 per cent respectively) at $10 \mu \mathrm{g} / \mathrm{mL}$. The methanolic extract, $\mathrm{n}$-hexane and chloroform fractions of $P$. longum had $\mathrm{IC}_{50}$ of $0.026,0.521$ and $1.554 \mathrm{mg} / \mathrm{mL}$ respectively.

\section{Larval motility assay (LMA)}

The loss of complete motility caused by the methanolic extract and its fractions at sixth and $12^{\text {th }} \mathrm{h}$ is tabulated as per cent mortality in Table 3 .

The methanolic extract of $P$. longum caused larval mortality of 100 per cent at higher doses of 125, 250, $500 \mathrm{mg} / \mathrm{mL}$. The chloroform fraction of the methanolic fruit extract of P. longum was effective even at $1.95 \mathrm{mg} / \mathrm{mL}$ causing 52.31 per cent mortality of $\mathrm{L}_{3}$ larvae and higher concentrations

Table 1: Qualitative phytochemical analysis of extracts and fractions of Piper longum.

\begin{tabular}{cccc}
\hline $\begin{array}{c}\text { Phyto- } \\
\text { constituents }\end{array}$ & $\begin{array}{c}\text { Methanolic } \\
\text { extract }\end{array}$ & $\begin{array}{c}\text { n-hexane } \\
\text { Fraction }\end{array}$ & $\begin{array}{c}\text { Chloroform } \\
\text { Fraction }\end{array}$ \\
\hline Steroids & + & + & - \\
Alkaloids & + & - & + \\
Tannins & + & + & + \\
Flavonoids & + & + & + \\
Glycosides & + & + & + \\
Cardiac & + & + & + \\
Glycosides & + & + & + \\
Phenolics & + & + & + \\
compounds & + & - & - \\
Diterpenes & + & + & + \\
Triterpenes & + & + & + \\
Saponins & - & + & + \\
\hline
\end{tabular}

of 250 and $500 \mathrm{mg} / \mathrm{mL}$ produced mortality of 93.75, 97.33, 100 and 100 per cent respectively.

No much difference in mortality was observed at $12^{\text {th }} \mathrm{h}$ between the extract and fractions. The $\mathrm{IC}_{50}$ values was calculated using mortality data at $12^{\text {th }} \mathrm{h}$. The methanolic extract, $\mathrm{n}$-hexane and chloroform fractions of P. longum had $\mathrm{IC}_{50}$ of $1.533,1.383$ and $2.324 \mathrm{mg} / \mathrm{mL}$ respectively.

\section{Larval migration inhibition assay (LMIA)}

The results of LMIA for the methanolic extract and its fractions from fruits of $P$. longum are tabulated in Table 4. A dose dependent increase in activity was noted with the extracts. Larval migration inhibition of 89.66 per cent was observed at lowest dilution $(500 \mathrm{mg} / \mathrm{mL})$ of the methanolic fruit extract. An inhibition of larval migration by 92.73 per cent was noticed for highest concentration $(500 \mathrm{mg} / \mathrm{mL})$ of $\mathrm{n}$-hexane fraction while the lowest concentration of fraction efficiently inhibited 44.23 per cent larvae from migrating.

The $\mathrm{IC}_{50}$ values for the methanolic extract, $\mathrm{n}$-hexane and chloroform fractions of $P$. longum had $\mathrm{IC}_{50}$ value of $4.412,2.301$ and $1.796 \mathrm{mg} / \mathrm{mL}$ respectively.

\section{Adulticidal assay on amphistomes}

The lowest concentration and the time taken to induce 50 and 100 per cent mortality are given in Table 5. The methanolic extract of $P$. longum was highly effective produced 50 and 100 per cent mortality of adult amphistomes at concentration of 1.95 and $7.91 \mathrm{mg} / \mathrm{mL}$ respectively within 105 and $85 \mathrm{~min}$ respectively. $\mathrm{IC}_{50}$ values for methanolic extract of P. longum was $5.493 \mathrm{mg} / \mathrm{mL}$ followed by $\mathrm{n}$-hexane and chloroform fractions with $\mathrm{IC}_{50}$ of 105.1 and 21.91 respectively.

\section{Selection of potent extract/fraction}

Based on the $\mathrm{IC}_{50}$ values, the potent extract/fraction was selected Table 6. The $\mathrm{IC}_{50}$ of $0.026 \mathrm{mg} / \mathrm{mL}$ was obtained for methanolic extract of fruits of $P$. longum in egg hatch assay (EHA) which was lowest value in the

Table 2: Effect of methanolic extract and fractions of Piper longum on egg hatch, (\% inhibition).

\begin{tabular}{|c|c|c|c|}
\hline \multirow{2}{*}{$\begin{array}{l}\text { Concentration } \\
(\mathrm{mg} / \mathrm{mL})\end{array}$} & \multicolumn{3}{|c|}{ Treatments } \\
\hline & MPL & n-HPL & CPL \\
\hline 1.95 & $88.89^{\mathrm{a}}$ & $75^{\mathrm{a}}$ & $58.33^{\mathrm{a}}$ \\
\hline 3.91 & $91.94^{\mathrm{b}}$ & $87.27^{\mathrm{b}}$ & $70^{\mathrm{b}}$ \\
\hline 7.81 & $89.09^{\mathrm{a}}$ & $88.46^{\mathrm{b}}$ & $80^{c}$ \\
\hline 15.63 & $94.12^{b, c}$ & $93.88^{c}$ & $94.55^{\mathrm{d}}$ \\
\hline 31.25 & $97.78^{\mathrm{d}, \mathrm{e}}$ & $100^{\mathrm{d}}$ & $100^{\mathrm{e}}$ \\
\hline 62.5 & $96^{\mathrm{c}, \mathrm{d}}$ & $100^{\mathrm{d}}$ & $100^{\mathrm{e}}$ \\
\hline 125 & $100^{\mathrm{e}}$ & $96.67^{e}$ & $100^{\mathrm{e}}$ \\
\hline 250 & $100^{\mathrm{e}}$ & $97.5^{\mathrm{e}}$ & $100^{\mathrm{e}}$ \\
\hline \multirow[t]{5}{*}{500} & $100^{\mathrm{e}}$ & $100^{\mathrm{d}}$ & $100^{\mathrm{e}}$ \\
\hline & \multicolumn{2}{|l|}{ Control } & \\
\hline & $6.25 \%$ Tween 80 & 0 & \\
\hline & Ivermectin $(10 \mu \mathrm{g} / \mathrm{mL})$ & 98.97 & \\
\hline & Thiabendazole $(10 \mu \mathrm{g} / \mathrm{mL})$ & 99.26 & \\
\hline
\end{tabular}

Pooled SE: 1.191

Note: MPL: Methanolic P. longum; n-HPL: n-Hexane P. longum; CPL: Chloroform $P$. longum. Values with different superscripts vary significantly within the column $(\mathrm{P}<0.05)$ 
Table 3: Effect of methanolic extract and fractions of Piper longum on larvae by $6^{\text {th }}$ and $12^{\text {th }} \mathbf{h}$ post exposure, (\% mortality)

\begin{tabular}{|c|c|c|c|c|c|c|}
\hline \multirow{3}{*}{$\begin{array}{l}\text { Concentration (mg/ } \\
\mathrm{mL})\end{array}$} & \multicolumn{6}{|c|}{ Treatments } \\
\hline & \multicolumn{2}{|c|}{ MPL } & \multicolumn{2}{|c|}{$n-H P L$} & \multicolumn{2}{|c|}{$\mathrm{CPL}$} \\
\hline & $6^{\text {th }}$ hour & $12^{\text {th }}$ hour & $6^{\text {th }}$ hour & $12^{\text {th }}$ hour & $6^{\text {th }}$ hour & $12^{\text {th }}$ hour \\
\hline 1.95 & $54.55^{\mathrm{a}}$ & $56.36^{\mathrm{a}}$ & $45^{\mathrm{a}}$ & $52.5^{\mathrm{a}}$ & $52.31^{\mathrm{a}}$ & $53.85^{\mathrm{a}}$ \\
\hline 3.91 & $78.57^{b}$ & $83.93^{b}$ & $63^{\mathrm{b}}$ & $69^{b}$ & $50^{\mathrm{b}}$ & $55^{\mathrm{a}}$ \\
\hline 7.81 & $86.05^{c}$ & $86.05^{c}$ & $66.94^{c}$ & $75.81^{c}$ & $63.33^{\mathrm{c}}$ & $70^{\mathrm{b}}$ \\
\hline 15.63 & $95.12^{\mathrm{d}}$ & $95.12^{\mathrm{d}}$ & $65^{\mathrm{d}}$ & $69.17^{b}$ & $58.33^{\mathrm{d}}$ & $63.33^{c}$ \\
\hline 31.25 & $95.83^{\mathrm{d}}$ & $97.92^{\mathrm{e}}$ & $76.25^{\mathrm{e}}$ & $81.25^{\mathrm{d}}$ & $76.92^{\mathrm{e}}$ & $83.08^{\mathrm{d}}$ \\
\hline 62.5 & $94.12^{\mathrm{d}}$ & $100^{\mathrm{f}}$ & $86^{\mathrm{f}}$ & $89^{e}$ & $93.75^{f}$ & $95^{\mathrm{e}}$ \\
\hline 125 & $100^{\mathrm{e}}$ & $100^{f}$ & $90^{\mathrm{g}}$ & $92.5^{\mathrm{f}}$ & $97.33^{\mathrm{g}}$ & $100^{f}$ \\
\hline 250 & $100^{\mathrm{e}}$ & $100^{\mathrm{f}}$ & $98.75^{\mathrm{h}}$ & $100^{\mathrm{g}}$ & $100^{\mathrm{h}}$ & $100^{f}$ \\
\hline 500 & $100^{\mathrm{e}}$ & $100^{f}$ & $100^{\mathrm{h}}$ & $100^{\mathrm{g}}$ & $100^{\mathrm{h}}$ & $100^{\mathrm{f}}$ \\
\hline Pooled SE & 0.989 & 0.807 & 0.9 & 0.790 & 1.008 & 0.949 \\
\hline \multicolumn{3}{|c|}{ Control } & \multirow{4}{*}{\multicolumn{4}{|c|}{$\begin{array}{l}\text { Note: MPL: Methanolic P. longum; n-HPL: n-Hexane P. longum; CPL: } \\
\text { Chloroform P. longum. } \\
\text { Values with different superscripts vary significantly within the column } \\
(\mathrm{P}<0.05)\end{array}$}} \\
\hline \multirow{2}{*}{\multicolumn{2}{|c|}{$\begin{array}{l}6.25 \% \text { Tween } 80 \text { in water } \\
\text { Ivermectin }(10 \mu \mathrm{g} / \mathrm{mL})\end{array}$}} & 2.9 & & & & \\
\hline & & 100 & & & & \\
\hline \multicolumn{2}{|c|}{ Thiabendazole $(10 \mu \mathrm{g} / \mathrm{mL})$} & 100 & & & & \\
\hline
\end{tabular}

Table 4: Effect of methanolic extract and fractions of Piper longum on larval migration, (\% inhibition).

\begin{tabular}{cccc}
\hline Concentration $(\mathrm{mg} / \mathrm{mL})$ & \multicolumn{3}{c}{ Treatments } \\
\cline { 2 - 4 } & MPL & $\mathrm{n}$-HPL & CPL \\
\hline 1.95 & $44.44^{\mathrm{a}}$ & $44.23^{\mathrm{a}}$ & $48.98^{\mathrm{a}}$ \\
3.91 & $46.27^{\mathrm{a}}$ & $57.14^{\mathrm{b}}$ & $67.74^{\mathrm{b}}$ \\
7.81 & $60.98^{\mathrm{b}}$ & $69.12^{\mathrm{c}}$ & $78.95^{\mathrm{c}}$ \\
15.63 & $57.69^{\mathrm{c}}$ & $72.92^{\mathrm{d}}$ & $82.61^{\mathrm{d}}$ \\
31.25 & $64.71^{\mathrm{d}}$ & $83.33^{\mathrm{e}}$ & $88.24^{\mathrm{e}}$ \\
62.5 & $72.09^{\mathrm{e}}$ & $82.43^{\mathrm{e}}$ & $97.83^{\mathrm{f}}$ \\
125 & $72.5^{\mathrm{e}}$ & $89.58^{\mathrm{f}}$ & $95.24^{\mathrm{f}}$ \\
250 & $83.78^{\mathrm{f}}$ & $87.04^{\mathrm{f}}$ & $97.22^{\mathrm{f}}$ \\
500 & $89.66^{\mathrm{g}}$ & $92.73^{\mathrm{g}}$ & $95.24^{\mathrm{f}}$ \\
\hline
\end{tabular}

\begin{tabular}{|cc|}
\cline { 2 - 3 } Control \\
\cline { 2 - 3 } $6.25 \%$ Tween 80 in water & 0 \\
Ivermectin $(10 \mu \mathrm{g} / \mathrm{mL})$ & 77.53 \\
Thiabendazole $(10 \mu \mathrm{g} / \mathrm{mL})$ & 93.65 \\
\hline
\end{tabular}

Pooled SE: 1.370

Note: MPL: Methanolic P. longum; n-HPL: n -Hexane P. longum;

CPL: Chloroform P. longum

Values with different superscripts vary significantly within the column $(\mathrm{P}<0.05)$ study. The $\mathrm{IC}_{50}$ for chloroform fraction of $P$. longum was consistently low in EHA, LMA and LMIA with IC $_{50}$ of 1.554, 2.324 and 1.796 respectively indicating its broad spectrum of activity. Hence the methanolic extract and its chloroform fraction was subjected for GCMS and FTIR analysis.

\section{FTIR analysis}

The results obtained from FTIR analysis is given in Figure 2 and Table 7.

\section{GCMS analysis}

Phytochemicals identified by GCMS and the spectrum obtained Figure 3 for methanolic $P$. longum is given below with their probability and respective retention time Table 8 .

\section{Acute Oral Toxicity Study}

No mortality was observed among rats administered with, methanolic extract of $P$. longum throughout the study period of 14 days. The rats in the study did not reveal any major chemical adverse effects post dose administration and in subsequent 14 days of the study period except for clinical signs of hypoactivity and mild discomfort for short duration. Rats sacrificed at the end of study period showed mild gross changes in liver at necropsy. The histopathology of the hepatic tissue revealed mild vascular changes.

\section{DISCUSSION}

The methanolic extract and its n-hexane and chloroform fractions of $P$. longum possessed promising anthelmintic activity up to the lowest concentration $(1.95 \mathrm{mg} / \mathrm{mL})$ employed causing more than 50 per cent inhibition of hatching. The methanolic extract of $P$. longum was highly 
potent followed by its hexane and chloroform fraction. The results obtained in larval motility assay indicated that the per cent of larval mortality increased with time and dose. The methanolic extract and n-hexane and chloroform fractions of $P$. longum was efficient causing complete larval mortality at highest concentration of $500 \mathrm{mg} / \mathrm{mL}$ within six hours and more than 50 per cent mortality of larvae even at lowest concentration $(1.95 \mathrm{mg} / \mathrm{mL})$ by $12^{\text {th }} \mathrm{h}$. From the $\mathrm{IC}_{50}$ values, $\mathrm{The}^{\mathrm{IC}} \mathrm{C}_{50}$ for methanolic extract and $\mathrm{n}$-hexane fraction of $P$. longum were in the range of $1.29-1.53 \mathrm{mg} / \mathrm{mL}$. The chloroform fraction of $P$. longum possessed lowest activity against $\mathrm{L}_{3}$ larvae with $\mathrm{IC}_{50}$ of $12.47 \mathrm{mg} / \mathrm{mL}$.

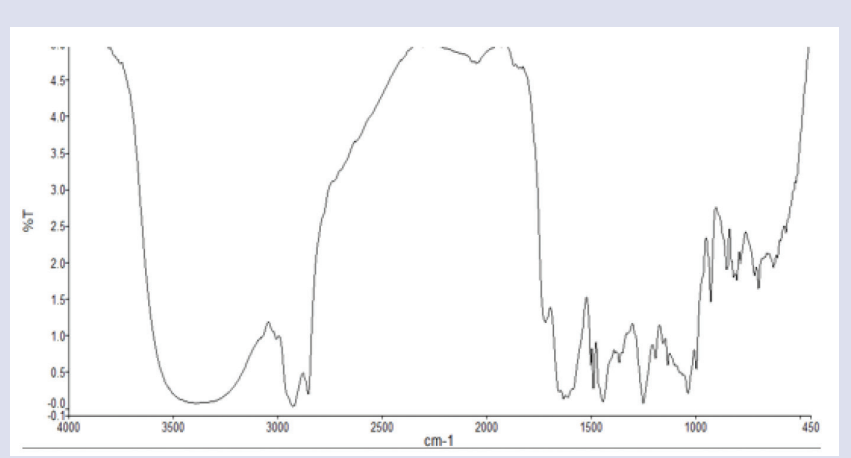

Figure 2: FTIR spectrum of methanolic extract of Piper longum.

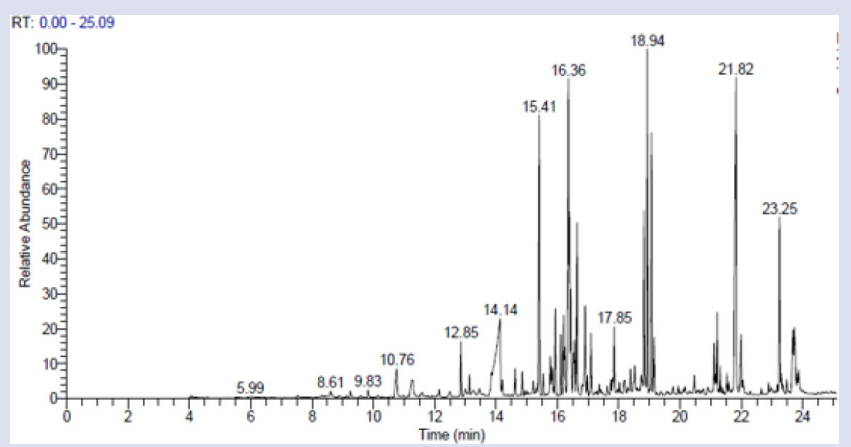

Figure 3: GCMS spectrum for methanolic extract of Piper longum.
Table 5: Minimum concentration and time producing 50 per cent and 100 per cent mortality of adult amphistomes, ( $\mathrm{mg} / \mathrm{mL}$ and minutes)

\begin{tabular}{ccccc}
\hline Extract/ & \multicolumn{2}{c}{$50 \%$ Mortality } & \multicolumn{2}{c}{$100 \%$ Mortality } \\
\cline { 2 - 5 } & $\begin{array}{c}\text { Concentration } \\
(\mathrm{mg} / \mathrm{mL})\end{array}$ & $\begin{array}{c}\text { Time } \\
\text { (minutes) }\end{array}$ & $\begin{array}{c}\text { Concentration } \\
(\mathrm{mg} / \mathrm{mL})\end{array}$ & $\begin{array}{c}\text { Time } \\
\text { (minutes) }\end{array}$ \\
\hline Methanolic & 1.95 & 105 & 7.81 & 85 \\
n-hexane & 15.63 & 115 & 31.25 & 120 \\
Chloroform & 7.81 & 105 & 15.63 & 110 \\
Thiabendazole & $10 \mu \mathrm{g} / \mathrm{mL}$ & 30 & $10 \mu \mathrm{g} / \mathrm{mL}$ & 45 \\
Control & & & & \\
Tyrodes & - & 120 & - & 150 \\
Control & & & & \\
$6.25 \%$ Tween & - & 120 & - & 150 \\
80 & & & &
\end{tabular}

Table 6: Inhibitory concentration-50 (IC50) based on in-vitro studies, $(\mathrm{mg} / \mathrm{mL})$.

\begin{tabular}{ccccc}
\hline Extract & EHA & LMA & LMIA & AMA \\
\hline MPL & 0.026 & 1.533 & 4.412 & 5.493 \\
n-HPL & 0.521 & 1.383 & 2.301 & 105.1 \\
CPL & 1.554 & 2.324 & 1.796 & 21.91 \\
\hline
\end{tabular}

Note: MPL: Methanolic P. longum; n-HPL: n -Hexane P. longum; CPL: Chloroform P. longum

Table 7: List of structurally similar compounds for methanolic extract of Piper longum as obtained by FTIR analysis.

\begin{tabular}{|c|c|}
\hline $\begin{array}{l}\text { Potent extract / } \\
\text { fraction }\end{array}$ & Structurally similar compounds \\
\hline Methanolic extract & $\begin{array}{l}\text { Piperine, Beta-estradiol, Farnesyl Acetate, } \\
\text { (-)-(1r)-menthyl Acetate, D(+)-galacturonic } \\
\text { Acid, Dimethyl Azelate, Piperonylamine, } \\
\text { C16-juvenile Hormone, Barbituric Acid, Bis(2- } \\
\text { ethylhexyl) Sebacate. }\end{array}$ \\
\hline
\end{tabular}

Table 8: List of compounds from methanolic extract of Piper longum on GCMS analysis.

\begin{tabular}{|c|c|c|c|c|c|}
\hline Compounds & $\begin{array}{l}\text { Retention } \\
\text { time } \\
\text { (minutes) }\end{array}$ & Probability & Compounds & $\begin{array}{l}\text { Retention } \\
\text { time } \\
\text { (minutes) }\end{array}$ & Probability \\
\hline 1-Butanol & 4.25 & 62.86 & Benzenepropanoic acid & 13.91 & 42.62 \\
\hline 1-Butanol & 4.37 & 51.15 & Hydrocinnamic acid & 14.13 & 47.27 \\
\hline 2-Thiazolidinecarboxamide & 5.99 & 49.10 & Methyleugenol & 14.94 & 73.09 \\
\hline 2,4-Dihydroxy-2,5-dimethyl-3(2H)-furan-3-one & 7.52 & 89.09 & Spathulenol & 17.75 & 45.42 \\
\hline Benzyl alcohol & 8.61 & 47.47 & Caryophyllene oxide & 17.85 & 45.42 \\
\hline Benzenemethanol & 9.13 & 44.17 & Spathulenol & 18.39 & 70.08 \\
\hline 1,6-Octadien-3-ol & 9.83 & 71.74 & Hexadecanoic acid & 21.59 & 73 \\
\hline 4H-Pyran-4-one & 10.76 & 93.74 & n-Hexadecanoic acid & 21.98 & 46.35 \\
\hline 2H-Pyrrol-2-one & 11.26 & 60.94 & 2,4-Pentadienoic acid & 22.65 & 62.22 \\
\hline 2-Piperidinone & 11.58 & 84.62 & 2,4-Pentadienoic acid & 23.25 & 70.32 \\
\hline N-Ethylhexahydro-1-Hazepine & 11.80 & 43.92 & $9,12,15$-Octadecatrienoic acid & 24.43 & 45.17 \\
\hline Benzenepropanoic acid & 12.85 & 62.74 & Benzenepropanoic acid & & \\
\hline
\end{tabular}


The methanolic extract, $\mathrm{n}$-hexane and chloroform fractions of $P$. longum were effective in inhibiting larval migration even at lowest concentration $(1.95 \mathrm{mg} / \mathrm{mL})$ with inhibition of $89.66,92.73$ and 95.24 per cent respectively. From the $\mathrm{IC}_{50}$ values, chloroform fraction of $P$. longum was most potent in inhibiting larval migration $\left(\mathrm{IC}_{50}=1.796 \mathrm{mg} / \mathrm{mL}\right)$ followed by $n$-hexane fraction and methanolic extract of $P$. longum with $\mathrm{IC}_{50}$ of 2.301 and $4.412 \mathrm{mg} / \mathrm{mL}$ respectively. The results of adult mortality assay indicated that all the extract/fractions possessed activity against adult amphistomes. The methanolic extract of $P$. longum caused 50 per cent mortality of amphistomes at $1.95 \mathrm{mg} / \mathrm{mL}$ and complete mortality at $7.81 \mathrm{mg} / \mathrm{mL}$. The chloroform fraction of $P$. longum was equally effective causing 50 per cent mortality at $7.81 \mathrm{mg} / \mathrm{mL}$ and 100 per cent mortality of adults at $15.63 \mathrm{mg} / \mathrm{mL}$ respectively. The $\mathrm{n}$-hexane fraction of $P$. longum caused 50 per cent mortality at $15.63 \mathrm{mg} / \mathrm{mL}$ while complete mortality was observed at concentration of $31.25 \mathrm{mg} / \mathrm{mL}$. The $\mathrm{IC}_{50}$ data obtained in the study suggested that the methanolic extract of $P$. longum fruit was highly potent $\left(\mathrm{IC}_{50}=5.493 \mathrm{mg} / \mathrm{mL}\right)$ followed by chloroform and hexane fractions with $\mathrm{IC}_{50}$ of 21.91 and $105 \mathrm{mg} / \mathrm{mL}$ respectively.

The extract/fraction can be effective as anthelmintic if it produces more than 90 per cent inhibition of egg hatching. ${ }^{26}$ The phytochemicals like tannins, phenols, flavonoids, sterols etc. present in the extracts and fractions of $P$. longum contributed to the anthelmintic potency of the fruits. ${ }^{27}$ Though the exact mechanism of how these plant chemicals because anthelmintic activity has not been established, certain hypothesis had been predicted. Destabilization of egg membranes led to penetration of plant extract into the egg and caused either embryonic mortality or prevented development of embryo within the egg. ${ }^{28}$

The polyphenolic compounds tannins were present in the methanolic extract of $n$-hexane and chloroform fractions of P. longum, interfered with energy generation in the nematode. Tannins cause mortality of the parasite by binding to the glycoprotein on the tegument of the parasite. ${ }^{29}$ The presence of terpenoids in methanolic extract of n-hexane and chloroform fractions of $P$. longum were considered to cause inhibition of egg hatching synergistically with other phytochemicals including alkaloids, tannins, flavonoids etc. Phenols and flavonoids were found in the methanolic extract of $\mathrm{n}$-hexane and chloroform fractions of $P$. longum which also contributed to anthelmintic activity. The results are in accordance with the reports of Saddiqe et al. ${ }^{25}$ who stated that phenols and flavonoids were the major components in S. nigrum contributing to anthelmintic potency of the plant. The flavonoid, terpenoid, and steroid rich ethanolic and dichloromethane extract of Phytolacca icosandra caused inhibition of larval motility and caused death of larvae. ${ }^{31}$ as reported in the present study.

The presence of terpenoids in methanolic extract, $n$-hexane and chloroform fractions of $P$. longum can be considered to cause death of amphistomes synergistically with other phytochemicals. Enwerem et al..$^{32}$ reported that adulticidal activity of terpenoids in Berlina grandiflora against Caenorhabditis elegans

Iqbal et al ${ }^{33}$ reported that the adulticidal activity of Zingiber officinale, Allium sativum and Ficus religiosa against $H$. contortus which was attributed to the presence of potent phytochemicals in the plants. Tannins are polyphenolic compounds which caused mortality of adult amphistomes, probably by its interaction with glycoprotein and cause functional disintegration of this layer. ${ }^{30}$

The GCMS analysis revealed the presence of piperidinone, hydrocinnamic acid, ethylhexahydro azepine, methyleugenol, hexadecanoic acid and caryophyllene oxide were identified in the methanolic extract of P. longum while octadecatrienoic acid, caryophyllene, caryophyllene oxide and hydrocinnamic acid were present in the chloroform fraction of $P$. longum. Similar compounds were isolated by Liu et al. ${ }^{23}$ from plants belonging to piperaceae family including spathulenol, piperitone, eugenol and caryophyllene. Mohammed et al..$^{34}$ isolated piperidine, benzofuran, spathulenol, pyrrolizin from $P$. nigrum which are in support to the present finding.

Anthelmintic activity of caryophyllene oxide in essential oils of aerial parts of Artemisia campestris spp, carboxylic acids (acetic acid, butanoic acid, hexadecanoic acid and propanoic acid), 1-monolinoleoylglycerol trimethylsilyl ether, caryophyllene, tetradecanoic acid, 9,12,15-octadecatrienoic acid and 2- pentanone from leaf of Melia composite and octadecanoic acid, hexadecanoic acid and sesquiterpenes from Cleome chelidonii has been reported previously. ${ }^{35,36,37,38}$

\section{CONCLUSION}

From the results of the study, it could be concluded that the methanolic extract and fractions of $P$. longum possessed potent anthelmintic activity. The chloroform fraction of $P$. longum possessed potent broad spectrum anthelmintic activity as it was effective against strongyle ova, larva and adult amphistomes at low $\mathrm{IC}_{50}$ values. Though the extracts possessed mild toxicity, the dose required for anthelmintic activity was very less and isolation of the active compounds can provide a lead for the development of a novel and safe anthelmintic.

\section{ACKNOWLEDGEMENT}

The authors acknowledge Kerala State Council for Science, Technology and Environment (KSCSTE) and Kerala Veterinary and Animal Sciences University, Kerala, India for the aid provided.

\section{CONFLICT OF INTEREST}

We declare that we have no conflict of interest.

\section{REFERENCES}

1. Bi S, Goyal PK. Anthelmintic effect of Natural Plant (Carica papaya) extract against the gastrointestinal nematode, Ancylostoma caninum in Mice. ISCA J. Biol. Sci. 2012;1(1):2-6.

2. Kumarasingha R, Preston S, Yeo TC, Lim DS, Tu CL, Palombo EA, et al. Anthelmintic activity of selected ethno-medicinal plant extracts on parasitic stages of Haemonchus contortus. Parasit. vectors. 2016;9(1):187-93.

3. Eguale T, Tilahun G, Debella A, Feleke A, Makonnen E. Haemonchus contortus: in vitro and in vivo anthelmintic activity of aqueous and hydro-alcoholic extracts of Hedera helix. Exp. Parasitol. 2007;116(4):340-5.

4. Arafa WM, Shokeir KM, Khateib AM. Comparing an in vivo egg reduction test and in vitro egg hatching assay for different anthelmintic against Fasciola species, in cattle. Vet. Parasitol. 2015;214(1):152-8.

5. Singh D, Swarnkar CP. Alternative methods of control of gastrointestinal nematodosis in small ruminants. Small Ruminants Emerging Diseases Contaiment under WTO Regime (Eds: VS Vihan, Ashok Kumar, VK Gupta and NP Singh)، Satish Serial Publishing House, Delhi; 2007:269-303.

6. Vlaminck J, Borloo J, Vercruysse J, Geldhof P, Claerebout E. Vaccination of calves against Cooperia oncophora with a double-domain activation-associated secreted protein reduces parasite egg output and pasture contamination. Int. J. Parasitol. 2015;45(4):209-13

7. Deepa CK, Darsana U, Sujith S, Priya MN, Juliet S. Effect of Mallotus phillipensis flower extracts against third stage larvae of Haemonchus contortus. Int. J. Appl. Pure Sci. Agric. 2015;1(3):19-23.

8. Feboli A, Laurentiz AC, Soares SC, Augusto JG, Anjos LA, Magalhaes LG, et al. Ovicidal and larvicidal activity of extracts of Opuntia ficus-indica against gastrointestinal nematodes of naturally infected sheep. Vet. Parasitol. 2016;226: 65-8

9. Gomes DC, De Lima HG, Vaz AV, Santos NS, Santos FO, Dias ER, et al. In vitro anthelmintic activity of the Zizyphus joazeiro bark against gastrointestinal nematodes of goats and its cytotoxicity on Vero cells. Vet. Parasitol. 2016;226:10-16.

10. Luoga W, Mansur F, Lowe A, Duce IR, Buttle DJ, Behnke JM. Factors affecting the anthelmintic efficacy of papaya latex in vivo: host sex and intensity of infection. Parasitol. Res. 2015;114(7):2535-41.

11. Khushbu C, Roshni S, Anar P, Carol M, Mayuree P. Phytochemical and therapeutic potential of Piper longum Linn a review. Int. J. Res. Ayurveda Pharm. 2011;2(1):157-61.

12. Sreelekha KP, Ajeesh KrishnaTP, Adarsh Krishna TP, Deepa PE, Udayan D, Juliet $S$ et al. Pharmaco-chemical characterization of leaves of Blumea mollis (D. Don) merr. from Western Ghats of Wayanad region of Kerala, India. J. Pharmacognosy Phytochem. 2017;6(4):319-23.

13. Deepa CK. Anthelmintic resistance in gastrointestinal nematodes of goats. M.V.Sc 
thesis, Kerala veterinary and animal sciences university, pookode. 2005;p62.

14. Sathianesan $V$, Peter CT. A modification of veglias method of faecal cultures. Kerala J. Vet. Sci. 1970;1:107-9.

15. Harborne JB. Phytochemical Methods: A guide for modern techniques of plant analysis (3 ${ }^{\text {rd }}$ Ed.). Chapmann and Hall, London. 1998;p302.

16. Sujith S, Deepa CK, Priya MN, Darsana U, Sreedevi R, Lucy KM. In-vitro Efficacy of various Extracts of Murraya koenigii Leaf Against Gastrothylax crumenifer. Int. J. Pharmac. Phytochem. Res. 2015;7:604-7.

17. Coles GC, Jackson F, Pomroy WE, Prichard RK, Samson-Himmelstjerna G, Silvestre $A$, et al. The detection of anthelmintic resistance in nematodes of veterinary importance. Vet. Parasitol. 2006;136(3):167-85

18. Avinash B, Supraja N, Charitha VG, Adeppa J, Prasad TNVKV. Evaluation of the anthelmintic activity (in vitro) of neem leaf extract mediated silver nanoparticles against Haemonchus contortus. Int. J. Pure App. Biosci. 2017;5:118-28.

19. Kotze AC, Coleman GT, Mai A, McCarthy JS. Field evaluation of anthelmintic drug sensitivity using in vitro egg hatch and larval motility assays with Necator americanus recovered from human clinical isolates. Int. J. Parasitol. 2005:35(4):445-53

20. Demeler J, Kuttler U, El-Abdellati A, Stafford K, Rydzik A, Varady M, et al. Standardization of the larval migration inhibition test for the detection of resistance to ivermectin in gastro intestinal nematodes of ruminants. Vet. Parasitol. 2010; 174(1):58-64

21. Jeyathilakan N, Murali K, Anandraj A, Basith SA. Anthelmintic activity of essential oils of Cymbopogon citratus and Ocimum sanctum on Fasciola gigantica, in vitro. J Vet Parasitol. 2010:24(2):151-4.

22. Swapna DPR, Junise V, Shibin P, Senthila S, Rajesh RS. Isolation, identification and antimycobacterial evaluation of piperine from Piper longum. Pharm. Lett. 2012;4:863-8.

23. Liu L, Song G, Hu Y. GC-MS Analysis of the Essential Oils of Piper nigrum L. and Piper longum L. Chromatographia. 2007;66(9-10):785-90.

24. Organisation of economic Cooperation and development (OECD). 2001a. OECD test guidlines-420, acute oral toxicity-fixed dose procedure. OECD guidelines for testing chemicals [on-line]. Organisation of economic Cooperation and development. Paris, France.Available:https://ntp.niehs.nih.gov/iccvam/suppdocs/ feddocs/oecd/oecd_gl420.pdf. 2017;14p.

25. Saddiqe Z, Maimoona AL, Khalid SA. Phytochemical analysis and anthelmintic activity of extracts of aerial part of Solanum nigrum L. Biologia. 2013;59:205-11.

26. Vercruysse J, Holdsworth $P$, Letonja T, Barth D, Conder G, Hamamoto K, et al. International harmonisation of anthelmintic efficacy guidelines. Vet. Parasitol.
2001;96(3):171-93

27. Botura MB, Santos JDG, Silva GD Lima HG Oliveira JVA, Almeida MAO et al. In vitro ovicidal and larvicidal activity of Agave sisalana Perr.(sisal) on gastrointestinal nematodes of goats. Veterinary Parasitology. 2013;192(1):211-7.

28. Rogers WP, Brooks F. The mechanism of hatching of eggs of Haemonchus contortus. Int. J. Parasitol. 1977;7(1):61-5.

29. Thompson DP, Geary TG. The Structure and Function of Helminth Surfaces Biochem. Molecular Biol. Parasit.1995;6:p203

30. Hoste $H$, Jackson F, Athanasiadou S, Thamsborg SM, Hoskin SO. The effects of tannin-rich plants on parasitic nematodes in ruminants. Trends Parasitol. 2006;22(6):253-61

31. Hernandez-Villegas MM, Borges-Argaez R, Rodriguez-Vivas RI, Torres-Acosta JF, Méndez-Gonzalez M, Caceres-Farfan M. Ovicidal and larvicidal activity of the crude extracts from Phytolacca icosandra against Haemonchus contortus. Vet. Parasitol. 2011;179(1):100-6.

32. Enwerem NM, Okogun JI, Wambebe CO, Okorie DA, Akah PA. Anthelmintic activity of the stem bark extracts of Berlina grandiflora and one of its active principles, Betulinic acid. Phytomedicine. 2001;8(2):112-4.

33. Iqbal Z, Nadeem QK, Khan MN, Akhtar MS, Waraich FN. In vitro anthelmintic activity of Allium sativum, Zingiber officinale, Curcurbita mexicana and Ficus religiosa. Int J Agri. Biol. 2001;3(4):454-7.

34. Mohammed GJ, Omran AM, Hussein HM. Antibacterial and Phytochemical Analysis of Piper nigrum using Gas Chromatography-Mass Spectrum and Fourier-Transform Infrared Spectroscopy. Int. J. Pharmacognosy Phytochem. Res. 2016;8(6):977-96

35. Judzentiene A, Budiene J, Butkiene R, Kupcinskiene E, Laffont-Schwob I, Masotti V. Caryophyllene oxide-rich essential oils of Lithuanian Artemisia campestris ssp. campestris and their toxicity. Natural product commun. 2010;5(12):1981-4

36. Zhu D. Inactivation of helminth eggs with short-and medium-chain fatty acids alone and in combinations at naturally occurring concentrations. M. Eng thesis Cornell University, Cornell. 2014;39p.

37. Jahirhussain G, Kala K, Ayyappan P, Muniappan P, Tamilselvan V, Rajkumar P Profiling the secondary chemical class of in vivo Melia composita willd. Leaf using ethanolic fraction. Worls J Pharm Res. 2015;4:1367-76.

38. Parimalakrishnan S, Akalanka D, Rajeswari J, Ravisingh K. Extraction and char acterization of phytoconstituents of Cleome chelidonii by GC/MS. Int J Chem Pharma Sci. 2015;6: 63-9.

\section{SUMMARY}

- Gastrointestinal infections among livestock are gaining much importance not merely due to its occurrence, but also due to wide spread anthelmintic resistance. Phytochemicals are ideal alternatives to combat the infection and resistance. The present study was conducted with the view to evaluate the in vitro ovicidal (EHA), larvicidal (LMA and LMIA) and adulticidal activity of methanolic extract and various fractions from fruits of Piper longum against strongyle ova, larvae and adult amphistomes. Fruits were collected, identified, shade dried and extracted with methanol and the extract was successively fractionated using different solvents. The extracts and fractions were diluted serially in 6.25 per cent tween 80 to obtain concentrations of $500,250,125,62.5,31.25,15.63,7.81,3.91$ and $1.95 \mathrm{mg} / \mathrm{mL}$. Ivermectin and thiabendazole at $10 \mu \mathrm{g} / \mathrm{mL}$ acted as positive control and the solvents as negative control. The in vitro anthelmintic activity was performed. IC $\mathrm{C}_{50}$ was calculated and GCMS, FTIR analysis and acute oral toxicity study (OECD No. 420) of potent extract/fraction was performed to know the structure of active ingredient.

- The fruits were identified and accession number 006 was obtained. The phytochemical analysis revealed the presence of flavonoids in all the extract and fractions while saponins were absent. All extract and fractions possessed in vitro anthelmintic activity. The methanolic extract was potent (IC of $0.026 \mathrm{mg} / \mathrm{mL}$ ) against strongyle ova while the chloroform fraction possessed potent activity on larval migration $\left(\mathrm{IC}_{50}=1.796 \mathrm{mg} / \mathrm{mL}\right)$. The methanolic extract was potent against adult amphistomes $\left(I C_{5}\right.$ of $5.493 \mathrm{mg} / \mathrm{mL}$ ) causing morphological changes in tegument, syncytium and parenchyma on histopathology. GCMS analysis of potent methanolic extract revealed the presence of piperidinone, hydrocinnamic acid, caryophyllene oxide etc. No observable clinical signs were detected during the acute oral toxicity study except initial hypo activity, pale discoloration of liver on post mortem and on histopathology mild vascular changes in liver was noticed.

- From the results of the study it could be concluded that the chloroform fraction of $P$. longum possessed broad spectrum anthelmintic activity as it was effective against strongyle ova, larva and adult amphistoes. Isolation of the active compounds can provide a lead for the development of a novel, safe anthelmintic which may have a novel mechanism of action. 


\section{GRAPHICAL ABSTRACT}

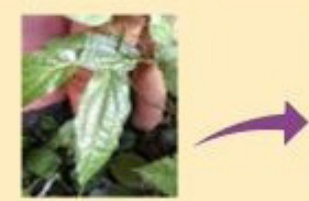

Piper longum L.

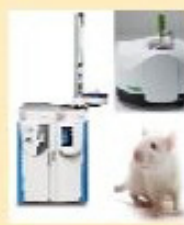

GCMS, FTIR Acute Toxicity

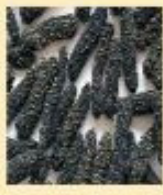

Dried fruits
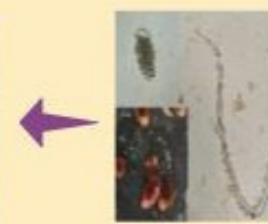

In-vitro Anthelmintic Activity
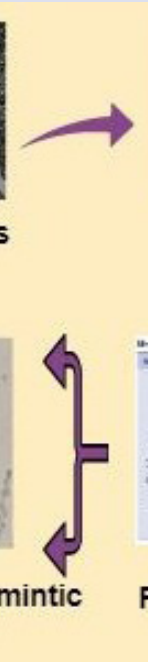

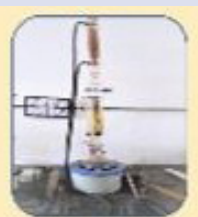

Extraction

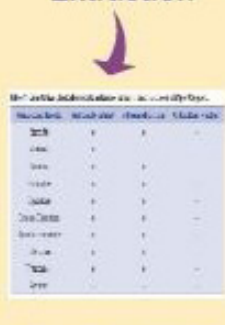

Phytochemical analysis

\section{ABOUT AUTHORS}

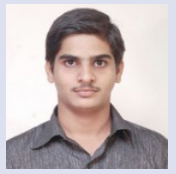

Dr. Krishnaprasad Ganapati Koorse: Is a postgraduate in Veterinary Pharmacology and Toxicology, from College of Veterinary \& Animal Sciences Mannuthy, Thrissur, Kerala. The major research interest in Ethnopharmacology. The M.V.Sc thesis was on the in-vitro anthelmintic activity study of various plant extracts.

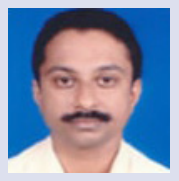

Dr. Sujith Samraj: Is a postgraduate in Veterinary Pharmacology and Toxicology, Presently working as Assistant Professor in the Department of Veterinary Pharmacology, College of Veterinary and Animal Sciences Mannuthy. The major research Interest is on Ethnopharmacology, Scientific validation of herbal medicines and Toxicology. Has published many articles on antimicrobial, antifungal and anthelmintic activity of herbal extracts. Presently working on anthelmintic resistance.

Cite this article: Krishnaprasad GK, Sujith S, Preethy J, Priya MN, Devi SS, Usha PTA, Surya S, Gleeja VL. Anthelmintic Activity of Fruit Extract and Fractions of Piper longum L. In vitro. Pharmacog J. 2018;10(2):333-40. 